\title{
Incorporating Outcomes Assessment and Rubrics into Case Instruction
}

\author{
Adva Dinur \\ Long Island University - Brooklyn Campus \\ Herbert Sherman \\ Long Island University - Brooklyn Campus
}

\begin{abstract}
Outcomes Assessment (OA) has emerged as the systemic mechanism for academic institutions to demonstrate to their stakeholders their viability as institutions that create and disseminate knowledge. Properly implementing outcomes assessment plans has been of paramount concern to postsecondary academic institutions whose accrediting bodies are requiring that institutions demonstrate that they have in fact achieved their goals and objectives. This study posits a preliminary methodology (a before/after study) for using grading rubrics, an instrument developed through outcomes assessment programs, for analyzing students' oral and written analyses of business cases. Results from the first round of data gathering from students' oral presentations are presented.
\end{abstract}

\section{Introduction and Background}

Outcomes Assessment ( $\mathrm{OA}$ ) has emerged as the systemic mechanism for academic institutions to demonstrate to their stakeholders their viability as institutions that create and disseminate knowledge. Properly implementing outcomes assessment plans has been of paramount concern to postsecondary academic institutions whose accrediting bodies are requiring that institutions demonstrate that they have in fact achieved their goals and objectives. For example, The Middle States Commission on Higher Education in their mission statement indicated that they are "dedicated to quality assurance and improvement through accreditation via peer evaluation. Middle States accreditation instills public confidence in institutional mission, goals, performance, and resources through its rigorous accreditation standards and their enforcement." (Middle States Commission on Higher Education, n.d.) Middle States has in fact produced a brochure that clarifies for these academic institutions Middle States' expectations regarding Institutional Assessment and Assessment of Student Learning entitled Assessing Student Learning and Institutional Effectiveness: Understanding Middle States Expectations. (Middle States Commission on Higher Education, 2005)

\section{Outcome Assessment and Schools of Business}

Outcome Assessment has not only affected institutions of higher learning as a whole but schools of business administration in particular since their specific supra accrediting bodies have adopted OA as the process in which schools must demonstrate student learning. IACBE, a business accrediting body addressing the needs of teaching institutions, claims that they are 
a leader in outcomes-based assessment and accreditation, in which excellence in business education is evaluated based on the results of the assessment of educational outcomes, rather than on prescriptive input standards. The IACBE believes that educational quality must be measured by outcomes rather than inputs, because inputs do not necessarily correlate with quality outcomes, since the quality of outcomes is dependent not only on inputs, but also on the processes used by the institution and its business programs to convert inputs to outcomes. The only accurate way to measure excellence in business education, therefore, is through the assessment of educational outcomes. (IACBE, n.d.)

AACSB, the oldest accrediting body of business schools, went one step further to more closely connect outcomes measures to performance standards. They

changed [the standards] to reflect the maturity of the "outcomes assessment" movement and need for improved accountability measures. The 2003 standards place[d] emphasis on direct assessments of student learning. In mandating direct assessment, AACSB expects accredited institutions to formulate specific learning goals and conduct appropriate direct assessments of learning for purposes of improving curricula when deficiencies or opportunities for improvement are found. (AACSB International Accreditation Coordinating Committee, AACSB International Accreditation Quality Committee, November 20, 2007)

Schools of Business have therefore been charged with the responsibility of not only documenting that student learning has occurred but that the learning has occurred at least in part due to the students' exposure to the college's curriculum and exp licitly the specific curriculum for the students' majors in business administration. This raises the question however as to where learning may actually occur in a student's college education and what role does classroom instruction play in their overall education.

\section{A Model of Student Centered Learning in Higher Education}

There is a growing acceptance that student learning should be a collaborative effort between the learner, the institution, and other institutional stakeholders; to paraphrase Hillary Clinton, it takes a college community to educate a student. (Clinton, August 27, 1996) Furthermore it is noted that learning can occur within any context. (Rowley and Sherman, 2004) It is therefore important to examine how higher education addresses the needs of the learner and also what is the context in which this learning takes place.

Rowley and Sherman (2004) have depicted the higher educational learning system as a series of building blocks which are necessary in order to construct a learning community. See Figure 1, below. 
Figure 1

The Higher Education Learning Community
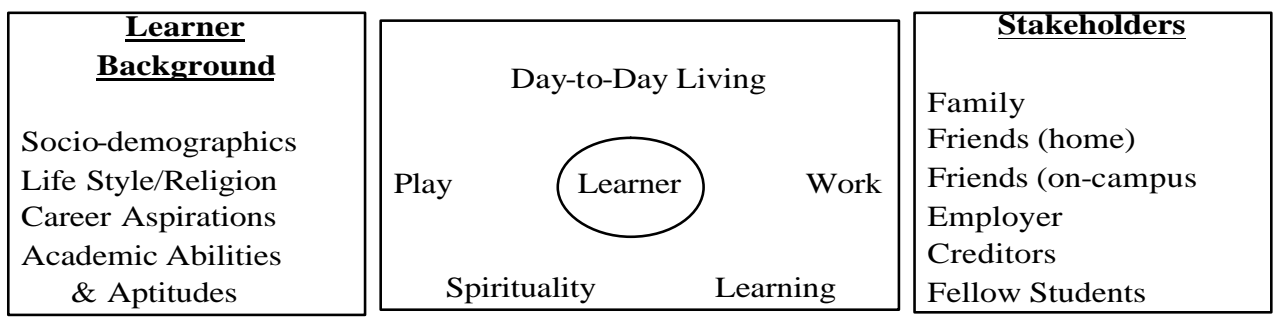

\begin{tabular}{|llll|}
\hline \multicolumn{4}{c|}{ University Stakeholders (internal) - Academic Planning } \\
Faculty & Academic Staff & Administrative Staff & Trustees \\
Academic Programs & Administrative Services & Other Learner Services \\
\hline
\end{tabular}

\begin{tabular}{|c|c|c|c|}
\hline \multicolumn{4}{|c|}{ University Stakeholders (external) - Strategic Planning } \\
\hline $\begin{array}{l}\text { Competitors } \\
\text { Mission }\end{array}$ & $\begin{array}{l}\text { Regulators } \\
\text { Goals }\end{array}$ & $\begin{array}{l}\text { Economy } \text { Technology } \\
\text { Competitive Position }\end{array}$ & $\begin{array}{l}\text { Society Donors/Alumni } \\
\text { Distintive Competencies }\end{array}$ \\
\hline
\end{tabular}

The lower layers of the model, the university's external stakeholders and the university's internal stakeholders, set the organizational context from which the institution's mission and objectives are formulated, implemented, and evaluated. The institution therein creates a strategic plan which enacts the institution's mission and goals, based upon its competitive position, distinctive competencies, and competitive advantage. (Rowley and Sherman, 2001)

The middle layer of the system consists of the faculty, administrators, and the Board of Trustees, who creates and institute academic and administrative services through the academic plan. The top of the system centers on the learner and the aspects of the learner's life during this period of learning (work, play, day-to-day living, learning, and spirituality). The wings connected to the learner, his or her background and his or her stakeholders; define the world of the learner. It is interesting to denote that actual academic "learning" is a small part of the learner's actual college experience, although Rowley and Sherman (2004) argued that it was the center of that experience. This learning includes the academic learners themselves, programs, faculty, administrators, staff, facilities, and equipment dedicated to the creation, dissemination and storage of both raw data and knowledge - in more traditional terms research, instruction, and library services. (Rowley and Sherman, 2003)

This broad-based definition of learning includes what has been categorized as either nontraditional or noncredit learning, and includes off-campus as well as on-campus programs, lecture series, and even high school acceleration programs. No matter in what context, location or learning mode, these activities are considered part of the learning process.

\section{Outcomes Assessment and Learning in Higher Education}

It is implied then that outcome assessment should capture the entire learner's 
experiences both within and outside the traditional learning environment (also known as the classroom - live or on-line); that all of the variables (independent, mediating, and moderating) that impact learning should be accounted for to determine which factors positively or negatively added to the learner's education. More specifically, outcomes assessment must discern what actions directly and indirectly taken by the university had both positive and negative impact on student learning (their abilities and aptitudes) and what actions the university can take both internally and externally to create a nurturing learning community.

The above statement acknowledges the fact that the university has control over some aspects of the learning environment and not others. For example, the university has control over its own curriculum, organizational structure, mission, goals and objectives, infrastructure, and other operational functions as part of the educational system value chain. Public institutions however may have less control over these variables since much of their policies and procedures are imposed by the State. (Burke, 2007) More importantly, numerous aspects of student learning are outside of an institution's direct purview. They may try to exert influence on external university stakeholders, the learner's stakeholders as well as try to influence the learner's career aspirations. (Pfeffer and Salancik, 1978)

Student learning, however, is most directly impacted by the university throug h course instruction; what the faculty member and the students do in the classroom or on-line. Outcome assessment instruments can therefore be readily applied to this unit of analysis since it is closest to the actual phenomenon being studied (Hitt et. al., 2007) and can be tailored to better fit the specific instructional methodology employed in each and every course. Students can then be directly assessed for course-specific learning while minimizing externalities impacting the learning process. (Campbell and Stanley, 1963) In management training and development this is akin to Boyatzis's (1982) notion of testing managers' competencies (performing a needs assessment prior to learning) to determine which management competencies that the managers lack before enrolling that managers in a training program. One would then provide competency-specific training, and then evaluate the training's impact on the managers' job performance.

\section{Levels of Objectives}

According to Bloom's (1956) Taxonomy, human thinking skills can be broken down into the following six categories.

1. Knowledge: remembering or recalling appropriate, previously learned information to draw out factual (usually right or wrong) answers. Use words and phrases such as: how many, when, where, list, define, tell, describe, identify, etc., to draw out factual answers, testing students' recall and recognition.

2. Comprehension: grasping or understanding the meaning of informational materials. Use words such as: describe, explain, estimate, predict, identify, and differentiate, etc., to encourage students to translate, interpret, and extrapolate.

3. Application: applying previously learned information (or knowledge) to new and unfamiliar situations. Use words such as: demonstrate, apply, illustrate, show, 
solve, examine, classify, and experiment, etc., to encourage students to apply knowledge to situations that are new and unfamiliar.

4. Analysis: breaking down information into parts, or examining (and trying to understand the organizational structure of) information. Use words and phrases such as: what are the differences, analyze, explain, compare, separate, classify, and arrange, etc., to encourage students to break information down into parts.

5. Synthesis: applying prior knowledge and skills to combine elements into a pattern not clearly there before. Use words and phrases such as: combine, rearrange, substitute, create, design, and invent, what if, etc., to encourage students to combine elements into a pattern that's new.

6. Evaluation: judging or deciding according to some set of criteria, without real right or wrong answers. Use words such as: assess, decide, measure, select, explain, conclude, compare, and summarize, etc., to encourage students to make judgments according to a set of criteria.

Learning objectives, and therefore the related assessment instruments, need to address the differing levels of learning embedded in a course. The classroom as a unit of analysis can therefore be broken down into specific learning objectives for the course by level of objective and specific assessment instruments developed and employed to evaluate those objectives. (Dwyer, 1991) It is suggested that

What you teach should determine how you need to assess learning. You should tie your objectives with your assessment to achieve the expected results ... after writing learning objectives you should think about how to assess the students' achievement of the different learning objectives.

1. Different learning objectives define the scope and methods of assessment.

2. Relating different levels of objectives with assessment instruments and all items that are graded will make sure you achieve your specific objectives.

3. Busy students need to know what they must do to achieve in the course: What are the assignments? What are the projects? How will they be graded? (Anonymous, n.d., March 6, 2008)

\section{Student Grading and Assessment}

Student grades are indications of how individual students performed on assessment instruments based upon existing performance standards and are provided to students as a feedback mechanism on prior learning as well as a reward/punishment for that performance. High scores on assessment instruments should inevitably lead to high grades in order to reinforce such behavior while low scores should act to negatively reinforce poor performance and lead to altered learning patterns.

Objective assessment instruments, those of a quantitative nature (true/false, multiple choice), are easy to score (and hence evaluate performance) but have the inherent flaw of usually addressing lower level learning objectives. These assessments do not depend on the assessor since it is clear to all assessors what the correct answers are. However these instruments are not without flaws: instructors may legitimately disagree about the best answer (sometimes more than one is correct); use of 'textbook language' encourages rote learning; the questions may contain irrelevant material; negative terms may be used unnecessarily (i.e. all of the above except) and are not emphasised; and 
the question provides clues to the correct answer. (Department of Education and Training, n.d.)

Qualitative or subjective assessments present their own problems. (Cashin, 1987) Most faculty members are either not aware of their evaluative criteria when evaluating for example essay exams or are not willing to share their performance expectations with their students. Faculty may have an implicit set of standards which they may or may not evenly apply. Students may be forced to guess as to what those criteria are (assuming that they are aware that this is an issue they need to deal with) even if learning objectives and course grading standards are distinctly listed on your course outline. Most faculty members 'wing' their evaluations, that is, they have their own internal standards, a mental model (Johnson-Laird and Byrne, 2000) so to speak, but never commit it to paper nor inform the students as to what the criteria of evaluation are that the students' works are being compared to. (Leach, Vega, and Sherman, forthcoming)

By not specifying evaluating criteria, students are being set up to misinterpret the question as well as possibly provide inappropriate answers. This may be merely due to not giving them enough direction and information about the assessment ins truments. Faculty need to develop assessment instruments that can be shared with students so as to minimize their task uncertainty (Galbraith, 1977) and maximize their opportunity for success. Faculty need to give students grades that reflect their knowledge as determined by the course learning objectives rather than their understanding of the assignment and their ability to guess instructor performance criteria. Having students guess at these criteria is counterproductive to the learning experience.

Assuming that clearly identified criteria for students' grades can be determined by the instructor for subjective assessments (based upon the learning objectives that the testing instrument is addressing), grades can also be determined based upon student improvement or creativity so that the student is reinforced for those accomplishments. An evaluative system such as this might result in building enthusiasm for the subject matter and learning in general. (Gopinath, 2004)

Regardless of assessment methodology, for outcomes assessment to be an effective process of continuous improvement for the institution, students must become cognizant of what learning they must demonstrate based upon the nuances of each assessment instrument.

\section{Outcomes Assessment and Grading Rubrics}

In order to more closely align learning objectives and student grading (and therein outcomes assessment) grading rubrics are used to guide faculty judgment when evaluating student performance on assessment instruments where there is more than one answer. "Rubrics are a way of explicitly stating the criteria for student work. They may lead to a grade or be part of the grading process. However, they are more specific, detailed, and disaggregated than a grade. Thus they can show strengths and weaknesses in student work." (Walvoord and Ehrmann, n.d.) Rubrics serve as 
behaviorally-anchored rating scales by clearly indicating what student responses would garner good grades and which responses would be considered unacceptable. See

Figure 2, below.

Figure 2

Sample Grading Rubric: Written Assignment Evaluation

(Anonymous, n.d., March 11, 2008a)

\begin{tabular}{|c|c|c|c|c|}
\hline Trait & A & B & C & D \\
\hline Content & $\begin{array}{l}\text { Writing is purposeful } \\
\text { with logic maintained } \\
\text { throughout. }\end{array}$ & $\begin{array}{l}\text { Maintains clear and } \\
\text { logical subject/position. }\end{array}$ & $\begin{array}{l}\text { Subject/position is } \\
\text { vague with no unifying } \\
\text { statement. Drifts or has } \\
\text { lapses in logic. } \\
\text { Consists of repetitions } \\
\text { and redundancies. }\end{array}$ & $\begin{array}{l}\text { Insufficient writing or } \\
\text { quality too poor to } \\
\text { judge if criteria are met. }\end{array}$ \\
\hline Support & $\begin{array}{l}\text { All major points fully } \\
\text { developed and } \\
\text { supported evenly by } \\
\text { specific detail } \\
\text { throughout the paper } \\
\text { (e.g. explanation, } \\
\text { evidence, examples, } \\
\text { figures, tables, or } \\
\text { graphs). Supporting } \\
\text { evidence is } \\
\text { understandable and } \\
\text { well-organized. }\end{array}$ & $\begin{array}{l}\text { All key points } \\
\text { developed and } \\
\text { supported by specific } \\
\text { detail. Some points } \\
\text { may not be as well } \\
\text { developed as others } \\
\text { (uneven). Supporting } \\
\text { evidence for main } \\
\text { points, but lacks depth. }\end{array}$ & $\begin{array}{l}\text { Some key points } \\
\text { developed by specific } \\
\text { detail, some may be } \\
\text { too general and/or lack } \\
\text { depth. Supporting } \\
\text { evidence is minimal. }\end{array}$ & $\begin{array}{l}\text { Insufficient or } \\
\text { repetitious writing that } \\
\text { fails to develop key } \\
\text { points. Lacks } \\
\text { supporting evidence } \\
\text { and/or supporting } \\
\text { evidence is unrelated } \\
\text { to key points. }\end{array}$ \\
\hline Organization & $\begin{array}{l}\text { Structure is clear, } \\
\text { appropriate and } \\
\text { effective. All } \\
\text { paragraphs are } \\
\text { appropriate and } \\
\text { purposeful. Coherence } \\
\text { (paragraph to } \\
\text { paragraph) and } \\
\text { cohesion (sentence to } \\
\text { sentence) are effective } \\
\text { throughout paper. All } \\
\text { points are logically } \\
\text { presented and } \\
\text { interrelated. }\end{array}$ & $\begin{array}{l}\text { Structure is clear and } \\
\text { appropriate to purpose. } \\
\text { Most major points are } \\
\text { appropriately } \\
\text { paragraphed. } \\
\text { Coherence (paragraph } \\
\text { to paragraph) and } \\
\text { cohesion (sentence to } \\
\text { sentence) are } \\
\text { demonstrated with } \\
\text { appropriate transitions. } \\
\text { Most points logically } \\
\text { presented and } \\
\text { organized. }\end{array}$ & \begin{tabular}{|l} 
Structure is evident. \\
May have inappropriate \\
or intrusive transitions \\
that disrupt the \\
progression of ideas. \\
Some major points \\
appropriately \\
paragraphed. Has \\
coherence (paragraph \\
to paragraph) but lacks \\
cohesion (sentence to \\
sentence) or vice \\
versa. May have one or \\
more minor \\
digressions.
\end{tabular} & $\begin{array}{l}\text { Structure is missing or } \\
\text { attempted but not } \\
\text { obvious to the reader. } \\
\text { Limited evidence of } \\
\text { appropriate } \\
\text { paragraphing. Little } \\
\text { structure within } \\
\text { paragraphs. May have } \\
\text { one or more major } \\
\text { digressions. }\end{array}$ \\
\hline Focus & $\begin{array}{l}\text { Clearly sets purpose of } \\
\text { paper through } \\
\text { introduction or } \\
\text { overview. Effective } \\
\text { conclusion that relates } \\
\text { to introduction and } \\
\text { unifies the writing. }\end{array}$ & $\begin{array}{l}\text { Clearly sets purpose of } \\
\text { paper through } \\
\text { introduction or } \\
\text { overview. Clear } \\
\text { conclusion. }\end{array}$ & $\begin{array}{l}\text { Subject/position } \\
\text { identified by only a } \\
\text { brief, general } \\
\text { introductory statement. } \\
\text { Conclusion is absent or } \\
\text { only a verbatim } \\
\text { reiteration of the } \\
\text { introduction. }\end{array}$ & $\begin{array}{l}\text { Subject/position (or } \\
\text { issue) is unclear. }\end{array}$ \\
\hline
\end{tabular}


Writing Mechanics

\begin{tabular}{|c|c|c|c|c|}
\hline Trait & A & $B$ & C & $\mathrm{D}$ \\
\hline $\begin{array}{l}\text { Sentences and } \\
\text { Paragraphs }\end{array}$ & $\begin{array}{l}\text { Usage of sophisticated } \\
\text { sentence patterns. } \\
\text { Paragraphs indicate } \\
\text { shift in thought and are } \\
\text { used to make } \\
\text { sequence of events } \\
\text { clear. }\end{array}$ & $\begin{array}{l}\text { Simple and some } \\
\text { complex sentences are } \\
\text { used. Some } \\
\text { paragraphing to show } \\
\text { sequence of } \\
\text { events/ideas. }\end{array}$ & $\begin{array}{l}\text { Sentence structure is } \\
\text { usually correct. Simple } \\
\text { sentences are used. } \\
\text { Little attempt made to } \\
\text { paragraph writing. }\end{array}$ & $\begin{array}{l}\text { Sentences do not make } \\
\text { sense. No } \\
\text { paragraphing. }\end{array}$ \\
\hline Word Choice & $\begin{array}{l}\text { Words are used } \\
\text { correctly and precisely. }\end{array}$ & $\begin{array}{l}\text { Acceptable vocabulary. } \\
\text { Words are } \\
\text { technologically } \\
\text { appropriate. }\end{array}$ & Simple vocabulary. & Incorrect vocabulary. \\
\hline Spelling & $\begin{array}{l}\text { Spelling is correct, } \\
\text { including complex and } \\
\text { irregular words. }\end{array}$ & $\begin{array}{l}\text { Spelling is generally } \\
\text { accurate. }\end{array}$ & $\begin{array}{l}\text { Frequent spelling } \\
\text { errors. }\end{array}$ & $\begin{array}{l}\text { Spelling errors interfere } \\
\text { with understanding. }\end{array}$ \\
\hline Punctuation & $\begin{array}{l}\text { A range of punctuation } \\
\text { including commas, } \\
\text { apostrophes, colons } \\
\text { and semicolons is used } \\
\text { accurately and } \\
\text { effectively. }\end{array}$ & $\begin{array}{l}\text { Periods and capitals } \\
\text { are used correctly and } \\
\text { punctuation is } \\
\text { beginning to be used } \\
\text { within sentences. }\end{array}$ & $\begin{array}{l}\text { Frequent punctuation } \\
\text { errors. }\end{array}$ & $\begin{array}{l}\text { Insufficient or lacks } \\
\text { punctuation. Incorrect } \\
\text { use of capital letters. }\end{array}$ \\
\hline
\end{tabular}

Note that the above rubric in Figure 2 provides specific guidelines for students to employ both in terms of the organization of the paper's content as well as writing mechanics. More specifically, each criterion is denoted as to those factors that determine the relative quality of a student's writing and each cell for each criterion describes a specific writing behavior with an associated assessment of performance.

\section{The Case Method and Outcomes Assessment}

The case method is one of the oldest methods of business instruction and is considered by most to be an excellent instructional methodology for teaching critical thinking and problem-solving skills. (Shugan, 2006) Professors usually use prepared cases, and the students are required to read, analyze, provide a solution and present their analysis and recommendations in written and/or oral form. Preparing a case allows students to practice analyzing a situation, formulating a solution strategy, and developing a preliminary implementation plan. The building blocks of this process are clear, and cases usually come with case notes which provide the analysis and solution to the case for the benefit of the instructor. (Anonymous, n.d., March 11, 2008b) This is mostly problem-based learning, with the work graded and evaluated subjectively by the instructor. (Armandi, Sherman, and Vega, 2004)

\section{The Preliminary Study}

While using cases is a valuable method of teaching, it also provides ample additional pedagogical opportunities which this manuscript seeks to explore. It is suggested in this 
study that the use of outcomes assessment methodologies such as evaluation rubrics, process feedback and peer evaluation will enhance the academic rigorousness of using cases in business courses, in this particular preliminary study, a strategic management class.

In addition to the usual advantages of the case method, students in this study will benefit in various ways given the specific team structure of the learning environment; these benefits include:

1. a deeper understanding of the subject matter

2. improved presentation and team work skills

3. higher level of involvement in the course

4. learning to align their learning efforts more closely to instructor requirements

5. providing an assessment that is more transparent and impartial and

6. a more comprehensive view of management as a whole.

This preliminary study, if successful in showing student performance improvement as well as increased student satisfaction, aims at redesigning the strategic management course so as to include outcomes assessment instruments, more specifically grading rubrics. Results from this beginning study may lead to a more comprehensive investigation of the effectiveness of the proposed pedagogy.

\section{Background and Rationale for the Study}

The case method is an extremely rich pedagogical instrument. In a strategy course it may be employed in a team learning environment, where 3-5 students prepare and present their work. The case method's value is in seeing how strategic planning and strategic management techniques actually work in the real world. This aids the learner in mastering the subject matter in various ways. First, through the study of actual business practices, learners are able to see how many of the theoretical underpinnings of the discipline work in affecting the course of organizational growth, prosperity, and survival. Second, it takes theory and tests it in practice. The results of this analysis are often the basis for further introspection and analysis. Third, the case study approach provides the learner with the opportunity to answer such questions as "What would I do in these circumstances? What kinds of decisions would I make to affect a positive difference? How would I know if I was or was not doing the right?" Second-guessing real-world decision makers is not only an interesting process; it is also an important educational process. Finally, case studies bring the subject matter to life. Most case studies are real, and the study of what actually happened makes it more meaningful for the learner. This active learning approach has many benefits over other methods of learning the subject matter (such as pure lecturing), and gives learners the opportunity to engage the studies on a first-person basis. (Naumes and Naumes, 1999)

These advantages brought the case method to the forefront of business education all over the world. Notwithstanding these important strengths, however, we wish to add outcomes assessment as well as a behavioral focus, which goes beyond the solution of the case and explores the challenging process of case analysis. In addition, this study 
aims to test the use of performance and evaluation rubrics as a pedagogical tool in improving students' learning and skill development. This is a viable enhancement to teaching cases, which could be easily adopted by any instructor. It has value not only to our students and university, but to the business education community as a whole, which uses cases so readily.

\section{Methodology}

This study involves an educational experiment that has already commenced, as part of the Long Island University business school's outcomes assessment initiative. MAN 151 "Managerial Planning and Control" is an advanced undergraduate class, which uses case analyses to teach the strategic management process. The students have been divided into teams of 4-5 students each, with each team analyzing and presenting three cases throughout the semester. All teams present the same cases. The students needed to use PowerPoint slides as a visual aid, as well as hand in a written outline of their presentation.

Three performance evaluation rubrics have been employed for these cases analyses (see Appendix A): one assessed the content of the presentation, and corresponds to an outline given to the students as a tool to assist with the case analysis preparation. The content of the first rubric was developed collaboratively between the course instructor and another faculty member who has expertise in strategic management and who has taught a similar course at another comparable institution. They examined the major content areas of the course, the assigned textbook, several other texts in the field, and determined the key areas of analysis which any strategic analysis of a firm should include (see Grant, 2008; Pearce and Robinson, 2005). These content areas also correspond to a highly complex grading rubric posed in Sherman, Rowley, and Armandi (2006).

The second and third rubrics are generic in nature. The second rubric assessed the presentation as a whole: non-verbal and vocal skills, time, visual aids, professionalism and more. The third rubric assessed the written component of the presentation. Both rubrics were developed by The Technology Applications Center for Educator Development, the Texas Center for Educational Technology. (http://www.tcet.unt.edu/ START/instruct/general/oral.htm)

Each presentation will be assessed and graded with the use of the rubrics as follows: All students in the audience complete the first two rubrics for each presentation they observe, as "peer evaluators". Besides the instructor, two additional evaluators will grade the presentations and written outlines: one a professor and the other a graduate student. Both professors are full-time employees of LIU, hold a Ph.D. in Management, and have over 10 years experience teaching and grading case presentations. The graduate student is a high-performing MBA student with some experience in grading and in case analysis. 
This data will be collected at two points during the semester, namely: at the first and the third presentations. After each presentation, the students will receive the usual feedback relating to the content of the presentation. In addition, we will be providing context feedback (on their presentation skills) as well. Each group will have feedback sessions with each of the participating professors. These sessions will focus on the group's task processes: how well did they perform as a group, how much cohesive ness and unity of performance have they achieved, how well they used verbal and non-verbal communications, how were their slides, and so on. The instructor will also provide as much assistance and additional feedback as each group requires.

At the end of the semester, the students will complete a survey, asking them to evaluate their experience in the class. How much improvement do they recognize in their performance and skill, and which elements of the case methodology have been most useful to them?

\section{Expected and Anticipated Outcomes}

This teaching study hopes to accomplish various outcomes, first of which is enhancing teaching outcomes for students in this class. Rather than sufficing with teaching the strategic management process, students are also provided with valuable management skills such as team work, presentation skills, giving and receiving feedback, maintaining working relationships with peers, and seeing the big picture of case analysis; process as well as outcome. It is believed that providing students with such skills would assist them not only in succeeding with their future courses, but also in the corporate world, where such proficiencies are crucial and sought-after.

Second, this study incorporates outcomes assessment as part of the teaching methodology in the classroom. This is an innovative pedagogy, which the authors are very excited about. It enhances an educational tool that is widely used in business schools, and as such would be relevant and valuable to hundreds of instructors worldwide.

Third, in this study evaluation rubrics are developed, utilized and tested. As popular as cases are in business schools, rubrics are seldom used. This teaching initiative develops as well as tests rubrics that, with the publication of this study, could be widely used as another enhancement to the case pedagogy. More importantly for students, developing and testing such rubrics is an important step towards a more transparent, unbiased student evaluation process. Due to the elusive nature of case teaching, students often complain of the vagueness of assessment tools and processes. The more students become familiar with the evaluation tool, the better they can prepare. This study takes an important step towards proving that the use of such rubrics is instrumental in aligning performance and evaluation, as well as providing students with a less frustrating and more fulfilling learning experience.

Fourth, this study provides outcomes assessment for employing such teaching methodologies: both objective and subjective. Objectively, it is hoped that there will be 
improvement in students' performance between the first and third case presentations. Subjectively, measures of students' perception of their advancement during the semester should allow researchers to assess to what degree students' value these teaching methodologies.

Finally, this research strives to be a first step in a more comprehensive investigation of the case method. While this initiative is innovative and fresh, it lacks empirical elements such as a control group, larger sample size, and a more comprehensive model, hypotheses and so fourth. This is a very modest design, which could be enlarged given positive results from this study as well as grant funding. Once the results show performance enhancement, student satisfaction, and skill development, one could then proceed with a newly designed course as well as a larger study.

\section{Evaluating the Study \& Preliminary Results}

To assess the achievement of our goals, of building students skills, providing better evaluation tools, testing rubrics and assessing students' satisfaction, students' progress as well as perceptions will be evaluated. First, students' case analysis, presentation and written report on their first and third course presentations will be assessed. As the complexity of the cases increase and the extent of the material grow throughout the semester, demands on the students increase as well. It is hoped that despite this increase, students' performances will improve. By measuring performance in various ways (peer, professor, outside evaluator, graduate student) it is hoped that satisfactory validity for this preliminary investigation is achieved. Analysis, public speaking, writing, team cooperation, coordination and leadership are but a few of the skills this study seeks to enhance in students.

Second, students' progress via self-assessment questionnaires will be evaluated at the conclusion of the semester. The researchers would inquire as to students' perceived progress, as well as the specific elements of the course that helped them most in achieving progress.

Initial data from students' first presentation (see Appendix B) have been collected. An examination of the descriptive statistics indicates that, in general, students scored average to above average (between 3-4 on a 5 point scale) in the content areas of analysis (goals to recommendations) but scored slightly lower (average to below average; between 2-3) in the presentation area. Students seemed to do quite well with industry analysis, internal analysis and SWOT Table and were least successful in vocalization and facial expression. Chi-squares and correlation analysis indicated that the evaluators (instructor, graduate assistant, outside evaluator, and students) in general had statistically significant agreement in evaluations in the content areas but slightly less agreement in the presentation areas, most notably with facial expressions, vocal skills, and time frame. 


\section{Conclusions}

It is believed that this initiative has already provided value to students in the MAN 151 course. The standard case teaching pedagogy has been enhanced by providing more process training and feedback, by clarifying evaluation scheme, by utilizing outcomes evaluation tools such as peer evaluations and by providing repeated team experiential exercises. It is hoped that this is merely a first step in a groundbreaking educational advancement both within LIU and in business education everywhere.

\section{REFERENCES}

AACSB International Accreditation Coordinating Committee, AACSB International Accreditation Quality Committee (November 20, 2007). AACSB assurance of learning standards: An interpretation. Retrieved from http://www.aacsb.edu/ accreditation/ Papers/AOLPaper-final-11-20-07.pdf, March 5, 2008.

Anonymous, (n.d.). Case method of analysis. Retrieved from http://www. referencefor business. com/ management/Bun-Comp/Case-Method-of-Analysis.html, March 11, 2008a.

Anonymous (n.d.). Grading rubrics for writing. Retrieved from http://www1.pacific. edu/ twrensch/ c129s06/rubric.html, March 11, 2008 b.

Anonymous (n.d.). Relate different levels of learning objectives to assessment. Retrieved from http://tlt.psu.edu/suggestions/research/Objectives_assessment.shtml, March 6, 2008.

Armandi, B., H. Sherman, and G. Vega (Fall 2004). Case research and writing: Three days in the life of Professor Moore. The CASE Journal 1, 1, 8-30.

Bloom, B. S. (1956). Taxonomy of educational objectives: Book 1, cognitive domain. New York: Longman.

Boyatzis, R. E. (1982). The competent manager: A model for effective performance. New York: John Wiley \& Sons.

Burke, J. C. (2007). Fixing the fragmented university: Decentralization with direction. Bolton, MA: Anker Publishing Company.

Campbell, D. T. and J. C. Stanley (1963). Experimental and quasi-experimental designs for research. Boston, MA: Houghton Mifflin Company.

Cashin, W. E. (1987). Improving essay tests. Idea Paper No. 17. Manhattan, KS: Center for Faculty Development and Evaluation, Kansas State University. 
Clinton, H. (August 27, 1996). It takes a village to raise a child. Retrieved from http://www. happinessonline.org/LoveAndHelpChildren/p12.htm, March 6, 2008.

Department of Education and Training (n.d.). Assessment professional learning module 2: Activity 2-4B designing better written tests. Victoria, Canada. Retrieved from www.eduweb.vic.gov.au /edulibrary public/teachlearn/student/activity2-4btests.ppt, March 6, 2008.

Dwyer, F. M. (1991). A paradigm for generating curriculum design oriented research questions in distance education. Second American Symposium Research in Distance Education, University Park, PA: Pennsylvania State University.

Galbraith, J. (1977). Organization design. Reading, Mass.: Addison-Wesley Publishing Company.

Gopinath, C. (2004). Exploring effects of criteria and multiple graders on case grading. Journal of Education for Business, 79, 6, 317-323.

Grant, R. (2008). Contemporary strategy analysis. $6^{\text {th }}$ Edition. United Kingdom: Blackwell Publishing.

Hitt, M. A., P. W. Beamish, S. E. Jackson, and J. E. Mathieu (December 2007). Building theoretical and empirical bridges across Levels: Multilevel research in management. The Academy of Management Journal, 50, 6, 1385-1400.

IACBE (n.d.). Philosophy of accreditation. Retrieved from http://www.iacbe.org /html/philosophy_of_accreditation.html, March 5, 2008.

Johnson-Laird, P. R. Byrne (May 2000). Mental models website: A gentle introduction. Retrieved from http://www.tcd.ie/Psychology/Ruth_Byrne/mental_models/, February 21, 2008.

Leach, T. G. Vega, and H. Sherman (in press). Professor Moore looks for a better way to grade student case analyses. The Case Journal.

Middle States Commission on Higher Education, (n.d.). Mission statement. Retrieved from http://www.msche. org/?Nav1= ABOUT\&Nav2=MISSION, March 5, 2008.

Middle States Commission on Higher Education (2005). Assessing student learning and institutional effectiveness: Understanding Middle States expectations. Retrieved from http://www.msche.org/publications_view.asp?idPublicationType=5\&txtPublication Type=Guidelines+for+Institutional+Improvement, March 5, 2008.

Naumes ,W. and M. J. Naumes (1999). The art \& craft of case writing. Thousand Oaks, Ca.: Sage Publications. 
Pearce, J. A. II and R. B. Robinson, Jr. (2005). Strategic management: Formulation, implementation, and control. $9^{\text {th }}$ Edition. New York: McGraw-Hill Irwin.

Pfeffer, J. and G. R. Salancik (1978). The external control of organizations: A resource dependence perspective. New York: Harper and Row.

Rowley, D. J. and H. Sherman (2001). From strategy to change: Implementing the plan in higher education (San Francisco, CA: Jossey-Bass Publishers).

Rowley, D. J. and H. Sherman (2003). The special challenges of academic leadership. Management Decisions, 41, 10, 1058-1063.

Rowley, D. J. and H. Sherman (2004). Academic planning: The heart and soul of the academic strategic plan. Lanham, MD: The University Press of America.

Shugan, S. M. (March-April 2006). Editorial: Save research - abandon the case method of teaching. Marketing Science 25, 2, 109-115.

Walvoord, B. and S. C. Ehrmann (n.d.). Appendix A: Sample rubrics for student classroom work (excerpted from The TLT Group Starter Kit Workbook). Retrieved from http://www.tltgroup.org/ resources/Flashlight/Rubrics.htm, March 6, 2008. 


\section{Appendix A \\ Evaluation Rubrics}

1. Case evaluating form: evaluating content

2. Oral presentation rubric: evaluating presentation

3. Written assignment evaluation: evaluating written presentation outline 


\title{
LONG ISLAND UNIVERSITY
}

\section{School of Business, Public Administration \& Information Sciences Spring 2008}

\author{
MAN 151 - Managerial Planning \& Control \\ Case Evaluation Form: Strategic Analysis
}

For each element, assess the content of the presentation between 1-5:

\begin{tabular}{|c|c|c|c|c|}
\hline 1 & 2 & 3 & 4 & 5 \\
\hline Non-existent & Poor & Acceptable & Good & Excellent \\
\hline
\end{tabular}

1. Strategic Direction: Goals and objectives $\begin{array}{lllll}1 & 2 & 3 & 4 & 5\end{array}$

2. Macro Environment: list opportunities and threats $1 \begin{array}{lllll}1 & 2 & 3 & 4 & 5\end{array}$

(Political/legal, Economic, Technological, Social, International)

3. Industry Environment (5 force analysis) $\quad 1 \quad 2 \quad 3 \quad 3 \quad 4 \quad 5$

How attractive is the industry? What are the main threats/opportunities there?

4. Internal Environment: $1 \begin{array}{lllll}\mathbf{2} & \mathbf{2} & \mathbf{3} & \mathbf{4} & \mathbf{5}\end{array}$

(Finance, Marketing, Operations, Human Resources, Other a reas in the value chain)

5. What is Cognex's distinctive competence \& competitive advantage? $\begin{array}{lllll}1 & 2 & \mathbf{3} & \mathbf{4} & \mathbf{5}\end{array}$

6. What is the central problem? $\begin{array}{lllll}1 & 2 & 3 & 4 & 5\end{array}$

7. Summarize your findings in a SWOT table $\begin{array}{lllll}1 & 2 & 3 & 4 & 5\end{array}$

8. What are the strategic options you can see? (pros and cons for each) $\begin{array}{llll}1 & 2 & 3 & 4\end{array}$ 5

9. Provide your final strategic recommendation. What are some actions they need to take to implement it? $\quad \begin{array}{lllll}1 & 2 & 3 & 4 & 5\end{array}$ 


\section{Oral Presentation Rubric}

\begin{tabular}{|c|c|c|c|c|}
\hline Criteria & 1 (Poor) & 2 (Fair) & 3 (Good) & 4 (Excellent) \\
\hline \multicolumn{5}{|l|}{ Nonverbal Skills } \\
\hline Eye Contact & $\begin{array}{l}\text { Does not attempt to } \\
\text { look at audience at } \\
\text { all, reads notes the } \\
\text { entire time }\end{array}$ & $\begin{array}{l}\text { Only focuses } \\
\text { attention to one } \\
\text { particular part of the } \\
\text { class, does not scan } \\
\text { audience }\end{array}$ & $\begin{array}{l}\text { Occasionally looks at } \\
\text { someone or some } \\
\text { groups during } \\
\text { presentation }\end{array}$ & $\begin{array}{l}\text { Constantly looks at } \\
\text { someone or some } \\
\text { groups at all times }\end{array}$ \\
\hline Facial Expressions & $\begin{array}{l}\text { Has either a } \\
\text { deadpan expression } \\
\text { of shows a } \\
\text { conflicting } \\
\text { expression during } \\
\text { entire presentation }\end{array}$ & $\begin{array}{l}\text { Occasionally } \\
\text { displays both a } \\
\text { deadpan and } \\
\text { conflicting } \\
\text { expression during } \\
\text { presentation }\end{array}$ & $\begin{array}{l}\text { Occasionally } \\
\text { demonstrates either } \\
\text { a deadpan OR } \\
\text { conflicting } \\
\text { expression during } \\
\text { presentation }\end{array}$ & $\begin{array}{l}\text { Gives audience } \\
\text { clues to what the } \\
\text { content of speech is } \\
\text { about; Appropriate } \\
\text { expression, never } \\
\text { notice a deadpan or } \\
\text { conflicting } \\
\text { expression }\end{array}$ \\
\hline Gestures & $\begin{array}{l}\text { No gestures are } \\
\text { notices }\end{array}$ & & & $\begin{array}{l}\text { Natural hand } \\
\text { gestures are } \\
\text { demonstrated }\end{array}$ \\
\hline Posture & $\begin{array}{l}\text { Sits during } \\
\text { presentation or } \\
\text { slumps }\end{array}$ & & $\begin{array}{l}\text { Occasionally slums } \\
\text { during presentation }\end{array}$ & $\begin{array}{l}\text { Stands up straight } \\
\text { with both feet on the } \\
\text { ground. }\end{array}$ \\
\hline \multicolumn{5}{|l|}{ Vocal Skills } \\
\hline Enthusiasm & $\begin{array}{l}\text { Shows absolutely no } \\
\text { interest in topic } \\
\text { presented }\end{array}$ & $\begin{array}{l}\text { Shows some } \\
\text { negativity toward } \\
\text { topic presented }\end{array}$ & $\begin{array}{l}\text { Occasionally shows } \\
\text { positive feelings } \\
\text { about topic }\end{array}$ & $\begin{array}{l}\text { Demonstrates a } \\
\text { strong positive } \\
\text { feeling about topic } \\
\text { during entire } \\
\text { presentation }\end{array}$ \\
\hline $\begin{array}{l}\text { Vocalized Pauses } \\
\text { (uh, well uh, um) }\end{array}$ & $\begin{array}{l}10 \text { or more are } \\
\text { noticed }\end{array}$ & 6-9 are noticed & 1-5 are noticed & $\begin{array}{l}\text { No vocalized pauses } \\
\text { noticed }\end{array}$ \\
\hline \multicolumn{5}{|l|}{ Content } \\
\hline Topic Announced & $\begin{array}{l}\text { Audience has no } \\
\text { idea what the report } \\
\text { is on }\end{array}$ & & $\begin{array}{l}\text { Vaguely tells } \\
\text { audience what report } \\
\text { is over }\end{array}$ & $\begin{array}{l}\text { Clearly explains what } \\
\text { the report is covering }\end{array}$ \\
\hline Time frame & $\begin{array}{l}\text { Presentation is less } \\
\text { than minimum time }\end{array}$ & $\begin{array}{l}\text { Presentation is more } \\
\text { than maximum time }\end{array}$ & & $\begin{array}{l}\text { Presentation falls } \\
\text { within required time } \\
\text { frame }\end{array}$ \\
\hline Visual Aid & $\begin{array}{l}\text { Poor, distracts } \\
\text { audience and is hard } \\
\text { to read }\end{array}$ & $\begin{array}{l}\text { Adds nothing to } \\
\text { presentation }\end{array}$ & $\begin{array}{l}\text { Thoughts articulated } \\
\text { clearly, but not } \\
\text { engaging }\end{array}$ & $\begin{array}{l}\text { Visual aid enhances } \\
\text { presentation, all } \\
\text { thoughts articulated } \\
\text { and keeps interest }\end{array}$ \\
\hline $\begin{array}{l}\text { Completeness of } \\
\text { Content }\end{array}$ & $\begin{array}{l}\text { One or more points } \\
\text { left out }\end{array}$ & $\begin{array}{l}\text { Majority of points } \\
\text { glossed over }\end{array}$ & $\begin{array}{l}\text { Majority of points } \\
\text { covered in depth, } \\
\text { some points glossed } \\
\text { over }\end{array}$ & $\begin{array}{l}\text { Thoroughly explains } \\
\text { all points }\end{array}$ \\
\hline $\begin{array}{l}\text { Professionalism of } \\
\text { Presentation }\end{array}$ & $\begin{array}{l}\text { Mumbles, audience } \\
\text { has difficulty hearing, } \\
\text { confusing }\end{array}$ & $\begin{array}{l}\text { Thoughts don't flow, } \\
\text { not clear, does not } \\
\text { engage audience }\end{array}$ & $\begin{array}{l}\text { Thoughts articulated } \\
\text { clearly, though does } \\
\text { not engage audience }\end{array}$ & $\begin{array}{l}\text { Presentation is } \\
\text { organized and the } \\
\text { interest level of the } \\
\text { audience is } \\
\text { maintained }\end{array}$ \\
\hline
\end{tabular}




\section{Written Assignment Evaluation}

Name

Date

Class

Assignment

\begin{tabular}{|c|c|c|c|c|}
\hline & $A$ & $\mathrm{~B}$ & $\mathrm{C}$ & $D$ \\
\hline Content & $\begin{array}{l}\text { An abundance of } \\
\text { material } \\
\text { Clearly related to topic; } \\
\text { Points are clear and } \\
\text { all } \\
\text { Evidence supports the } \\
\text { discussion }\end{array}$ & $\begin{array}{l}\text { Sufficient } \\
\text { information that } \\
\text { Relates to topic; } \\
\text { many good } \\
\text { points but uneven } \\
\text { balance } \\
\text { or little variation }\end{array}$ & $\begin{array}{l}\text { There is a great } \\
\text { deal of information } \\
\text { not clearly related to } \\
\text { the topic }\end{array}$ & $\begin{array}{l}\text { Topic not clearly } \\
\text { stated; information } \\
\text { insufficient or } \\
\text { superfluous }\end{array}$ \\
\hline Organization & $\begin{array}{l}\text { The assignment is well } \\
\text { constructed; it is } \\
\text { succinct and provides } \\
\text { even transitions; } \\
\text { headings and sub- } \\
\text { headings are well } \\
\text { constructed }\end{array}$ & $\begin{array}{l}\text { Most information } \\
\text { in logical } \\
\text { sequence but } \\
\text { transitions or flow } \\
\text { is difficult }\end{array}$ & $\begin{array}{l}\text { Concept and ideas } \\
\text { are loosely } \\
\text { connected; lacks } \\
\text { clear transitions, } \\
\text { choppy }\end{array}$ & $\begin{array}{l}\text { Presentation is } \\
\text { choppy or } \\
\text { disjointed; } \\
\text { development of } \\
\text { topic is vague; lacks } \\
\text { order }\end{array}$ \\
\hline Materials & $\begin{array}{l}\text { Balanced use of } \\
\text { outside sources or } \\
\text { graphical material; } \\
\text { selection of references } \\
\text { adds to the discussion }\end{array}$ & $\begin{array}{l}\text { Sources and } \\
\text { graphical material } \\
\text { adequate, but not } \\
\text { varied or } \\
\text { compelling }\end{array}$ & $\begin{array}{l}\text { Sources or } \\
\text { graphical material } \\
\text { present but do not } \\
\text { fully connect to the } \\
\text { topic }\end{array}$ & $\begin{array}{l}\text { Few or no outside } \\
\text { references or } \\
\text { graphical material } \\
\text { that add to the topic }\end{array}$ \\
\hline Mechanics & $\begin{array}{l}\text { Presentation captures } \\
\text { the reader's attention; } \\
\text { no grammatical or } \\
\text { spelling errors; } \\
\text { sources are cited } \\
\text { correctly }\end{array}$ & $\begin{array}{l}\text { Presentation } \\
\text { adequate; few } \\
\text { grammatical or } \\
\text { spelling errors; } \\
\text { style errors in } \\
\text { citation }\end{array}$ & $\begin{array}{l}\text { Presentation } \\
\text { uninteresting; } \\
\text { several grammatical } \\
\text { or spelling errors; } \\
\text { citation style not } \\
\text { correct }\end{array}$ & $\begin{array}{l}\text { Presentation bland; } \\
\text { pervasive } \\
\text { grammatical or } \\
\text { spelling errors; style } \\
\text { and citation errors } \\
\text { numerous }\end{array}$ \\
\hline
\end{tabular}

Evaluation

\begin{tabular}{|l|l|l|l|l|}
\hline & A & B & C & D \\
\hline Content & & & & \\
\hline Organization & & & & \\
\hline Materials & & & & \\
\hline Mechanics & & & & \\
\hline
\end{tabular}

ASSIGNMENT GRADE 


\section{Appendix B \\ Preliminary Data Analysis}

This study includes a comparison between two sets of data: one collected during the first presentation (out of three during the semester), and one collecting during the third and last presentation. The first presentation already took place, on February 21, and data were collected with rubrics 1 and 2 from Appendix A above. We have conducted preliminary descriptive statistics:

1. Min, Max, Mean, Std.

2. Summary of Chi-squares, and Pearson Correlations of evaluator and survey variables. (Crosstabs available upon request.)

\section{Descriptive Statistics}

\begin{tabular}{|l|r|r|r|r|r|}
\hline & \multicolumn{1}{|c|}{$\mathrm{N}$} & Minimum & Maximum & \multicolumn{1}{l|}{ Mean } & Std. Deviation \\
\hline eval & 159 & 1.00 & 4.00 & 3.7358 & .74164 \\
day & 159 & 1.00 & 2.00 & 1.3459 & .47717 \\
group\# & 159 & 1.00 & 7.00 & 3.6918 & 1.98076 \\
goals & 158 & 1.00 & 5.00 & 3.8323 & .91277 \\
macroenv & 157 & 2.00 & 5.00 & 3.7166 & .84024 \\
industenv & 156 & 2.00 & 5.00 & 3.8782 & .81986 \\
interenv & 158 & 1.00 & 5.00 & 3.9146 & .79847 \\
competadv & 148 & 1.00 & 5.00 & 3.7264 & .87157 \\
problem & 152 & 1.00 & 5.00 & 3.7171 & .93616 \\
SwOTtabl & 153 & 2.00 & 5.00 & 3.9314 & .84693 \\
options & 151 & 1.00 & 5.00 & 3.8675 & .88638 \\
recommend & 152 & 1.00 & 5.00 & 3.9474 & .83022 \\
eyecontact & 92 & 1.00 & 4.00 & 2.7772 & .86241 \\
facialexpre & 91 & 1.00 & 4.00 & 2.6868 & .73654 \\
gestures & 90 & 1.00 & 4.00 & 2.8278 & 1.14451 \\
posture & 91 & 2.00 & 4.00 & 3.4286 & .72866 \\
vocalskills & 28 & 2.00 & 4.00 & 3.1071 & .56695 \\
enthusiasm & 93 & 1.00 & 4.00 & 2.7742 & .80594 \\
vocpause & 94 & 1.00 & 4.00 & 2.6489 & 1.04426 \\
content & 28 & 2.00 & 4.00 & 3.1429 & .59094 \\
topicannou & 94 & 1.00 & 4.00 & 3.3989 & .68226 \\
timeframe & 86 & 2.00 & 4.00 & 3.4651 & .82173 \\
visualaid & 94 & 1.00 & 4.00 & 3.0904 & .69159 \\
completens & 94 & 1.00 & 4.00 & 2.9681 & .71395 \\
professpres & 94 & 1.00 & 4.00 & 2.8989 & .79169 \\
unknown & 3.00 & 3.00 & 3.0000 & .00000 \\
Valid N (listwise) & 0 & & & & \\
\hline
\end{tabular}




\section{Preliminary Results \\ Summary of Chi-Squares/Pearson Correlations of \\ "All Evaluators" by all Rubric Variables ( $N=159)$}

\section{Chi-Square \\ Pearson Correlation}

\begin{tabular}{|c|c|c|c|c|}
\hline Variables & Value & Significance & Value & Significance \\
\hline Group \# & .767 & 1.00 & -.056 & .485 \\
\hline Goals & 43.704 & .000 & .159 & .046 \\
\hline Macro Env & 110.011 & .000 & .383 & .000 \\
\hline Industry Env & 67.578 & .000 & .262 & .001 \\
\hline Internal Env & 31.909 & .007 & .101 & .207 \\
\hline Competit Adv & 89.641 & .000 & .240 & .003 \\
\hline Problem & 72.747 & .000 & .154 & .059 \\
\hline SWOT Table & 72.896 & .000 & .145 & .073 \\
\hline Options & 52.490 & .000 & .103 & .206 \\
\hline Recommend & 52.882 & .000 & .198 & .014 \\
\hline Eye Contact & 50.719 & .000 & .176 & .094 \\
\hline Facial Express & 41.494 & .001 & .131 & .216 \\
\hline Gestures & 35.980 & .000 & .243 & .021 \\
\hline Posture & 39.802 & .000 & .148 & .161 \\
\hline Vocal Skills & 3.158 & .206 & .259 & .183 \\
\hline Enthusiasm & 86.985 & .000 & .261 & .012 \\
\hline Vocal Pause & 18.896 & .026 &. .031 & .764 \\
\hline Content & 4.383 & .625 & .010 & .959 \\
\hline Topic Announc & 25.418 & .013 & .224 & .030 \\
\hline Time Frame & 5.412 & .492 &. .185 & .087 \\
\hline Visual Aid & 37.941 & .000 & .150 & .150 \\
\hline Completeness & 96.668 & .000 & .285 & .005 \\
\hline Professional & 28.863 & .004 & .308 & .003 \\
\hline
\end{tabular}

